\title{
Failure of an expandable cage-plate cervical vertebral body replacement: case report of a device related complication
}

\author{
Genişleyebilen kafes-plak servikal vertebral gövde replasmanında başarısızlık: \\ Cihazla ilişkili komplikasyon üzerine olgu sunumu
}

Klemens Trieb, MD., Stephan Koch, MD.

Department of Orthopaedics, Klinikum Wels-Grieskirchen, Austria

\begin{abstract}
Instabilities of the cervical spine after complete or incomplete corpectomy may be the result from resection due to stenosis induced myelopathy, tumors, infections or fractures. In this article, we report a 49-year-old female patient after surgical decompression and stabilization at $\mathrm{C} 5 / 7$ with permanent cervicobrachialgia due to cervical stenosis at $\mathrm{C} 5 / 7$. Corpectomy of C6 and stabilization of C5/7 were performed with a combination of cage and plate. At an outpatient control 16 months after reoperation, the patient complained of neck pain, while the control X-ray showed a fracture of the implant. Due to instability of the device, a revision was indicated, resulting in removal of all components with restabilization. Definitive stabilization was performed with a PINA ${ }^{\circledR}$ cage, discectomy and cage implantation at $\mathrm{C} 4 / 5$ and $\mathrm{C} 7 / \mathrm{Th} 1$ and a plate from $\mathrm{C} 4$ to $\mathrm{Th} 1$ with screw fixation in $\mathrm{C} 4 / 5 / \mathrm{Th} 1$. Postoperative course was complication free and the patient was without pain or neurological symptoms at follow-up after 12 months with all implants in radiologically regular position. To the best of our knowledge, this is the first case report to describe such a complication.
\end{abstract}

Keywords: Arthroplasty; breakthrough pain; replacement; spine.

Instabilities of the cervical spine after complete or incomplete corpectomy may be the result from resection due to stenosis induced myelopathy, tumors, infections or fractures. ${ }^{[1-5]}$ Expandable and non-expandable cages have gained acceptance for replacement of the vertebral body. Stabilization can be achieved by additional anterior plating or posterior stabilization by a rod and screw system. Alternatively, a direct fixation of the cages with fixation wings is possible, a combination of two systems in one - cage

\section{$\ddot{O} Z$}

Komplet veya inkomplet korpektomi sonrası servikal omurgada instabilite stenozun indüklediği miyelopati, tümörler, enfeksiyonlar veya kırıklara bağlı rezeksiyondan kaynaklanabilir. Bu yazıda, C5/7'de servikal stenoz nedeniyle cerrahi dekompresyon ve kalıcı servikobrakiyalji ile C5/7'de stabilizasyon sonrasında 49 yaşında bir kadın hasta sunuldu. C6'da korpektomi ve C5/7'de stabilizasyon kafes ve plak kombinasyonu ile yapıldı. Tekrar ameliyattan 16 ay sonraki ayaktan kontrolde hasta boyun ağrısından yakınırken kontrol röntgeninde implantta kırık görüldü. Cihazdaki instabilite nedeniyle revizyon endike olduğundan restabilizasyon ile tüm bileşenler çıkartıldı. Kesin stabilizasyon PINA ${ }^{\circledR}$ kafesi, diskektomi ve $\mathrm{C} 4 / 5$ ve $\mathrm{C} 7 / \mathrm{Th} 1$ kafes implantasyonu ve C4/5/Th1'de vida fiksasyonu ile C4'ten Th1'e bir plak ile yapıldı. Ameliyat sonrası seyir komplikasyonsuzdu ve 12 ay sonraki takipte hastada ağrı veya nörolojik semptom yoktu ve tüm implantlar radyolojik olarak düzgün konumda idi. Bildiğimiz kadarıyla böyle bir komplikasyonu açıklayan ilk olgu sunumu budur.

Anahtar sözcükler: Artroplasti; ani ağrı; replasman; omurga.

and fixation system. ${ }^{[6,7]}$ Thus, donor site complications are avoided and fast and strong reconstruction of the anterior column is provided under normal healing conditions. This report presents a case of failure and its treatment. ${ }^{[8]}$

\section{CASE REPORT}

A 49-year-old female patient presented with therapy refractory pain 16 months after surgery in another department. Surgical decompression and

- Received: April 04, 2017 Accepted: June 21, 2017

- Correspondence: Prof. Klemens Trieb, MD. Department of Orthopaedics Klinikum Wels-Grieskirchen, Grieskirchnerstr. 42, 4600 Wels, Austria Tel: +43724241592308 e-mail: Klemens.trieb@klinikum-wegr.at 


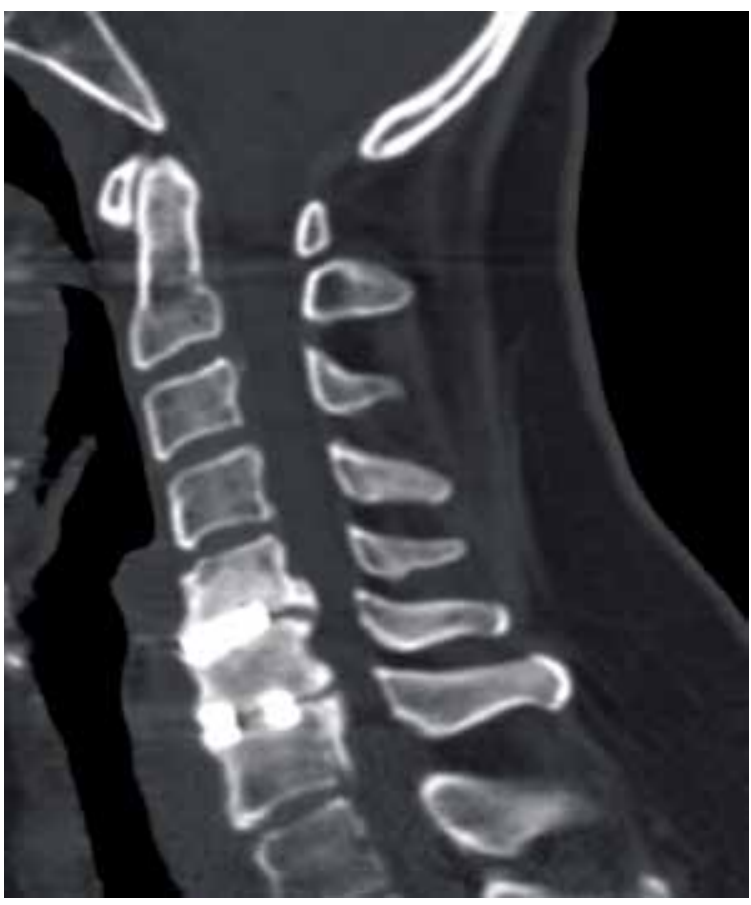

Figure 1. Lateral X-ray of cervical spine after surgery with persisting stenosis and pain.

stand-alone stabilization at $\mathrm{C} 5 / 7$ were performed (Figure 1). Permanent left C6 cervicobrachialgia was treated conservatively including computed tomography (CT) guided infiltrations without relief of symptoms for more than one year. After presenting at our department, a new $\mathrm{CT}$ was performed resulting in a cervical stenosis at C5/7 with in situ cages. Due to clinical and imaging findings, a reoperation of the cervical spine was performed by corpectomy of C6 and stabilization of C5/7 with a combination of a cage and plate (ADDplus, anterior distraction device; Ulrich medical, Ulm, Germany) (Figure 2a and b). An ADDplus implant (CS 2253-X) with $0^{\circ}$ angulation, $12 \mathrm{~mm}$ diameter and a distraction height of $13-18 \mathrm{~mm}$ was used, while fixation was established by a locking screw and four osmium screws (CS 1300-X) with a diameter of $5 \mathrm{~mm}$. Postoperative images showed the implant in situ with regular orientation. The clinical course was without complications. At an outpatient control 16 months after reoperation, the patient complained of neck pain without trauma or neurological deficit. The control X-ray showed a fracture of the implant - a breakage of the cage on the lower rim could be detected (Figure 3). Due to instability of the device, a revision was indicated, resulting in removal of all components with restabilization. The choice of implant was dependent on the intraoperative situs. The osmium screws could not be removed totally, due to breakage of the distal parts staying in the bone (Figures 4-7). Instability of the adjacent levels of $\mathrm{C} 4 / 5$ and $\mathrm{C} 7 / \mathrm{Th} 1$ was the indication for inclusion of the two segments. Definitive stabilization was performed with a PINA ${ }^{\circledR}$ cage (PINA ${ }^{\circledR}$ Medizintechnik Vertriebs AG, Thayngen, Schweiz), discectomy and cage implantation at $\mathrm{C} 4 / 5$
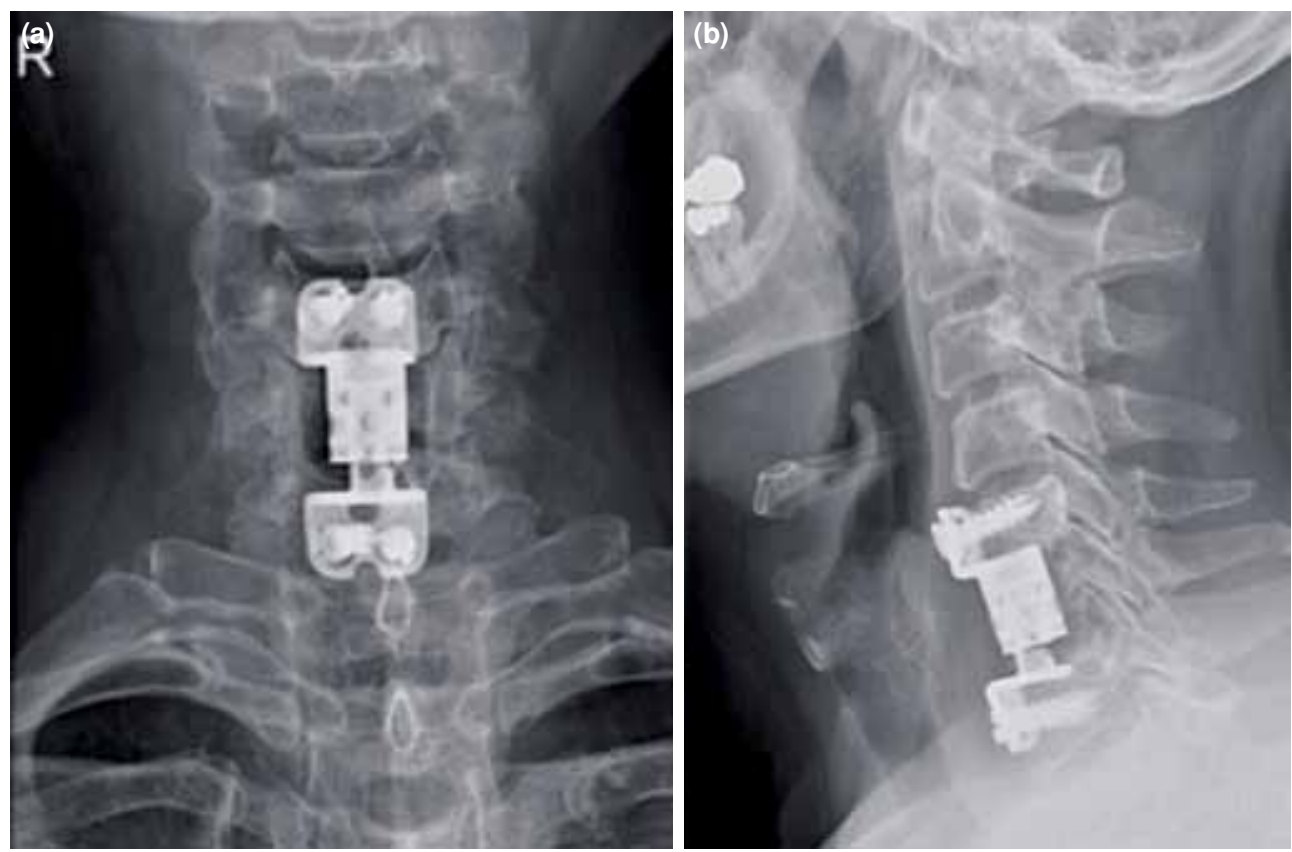

Figure 2. (a, b) Postoperative radiograph after corpectomy at C6 and implantation of ADDplus device (a: anteroposterior view, b: lateral view). 


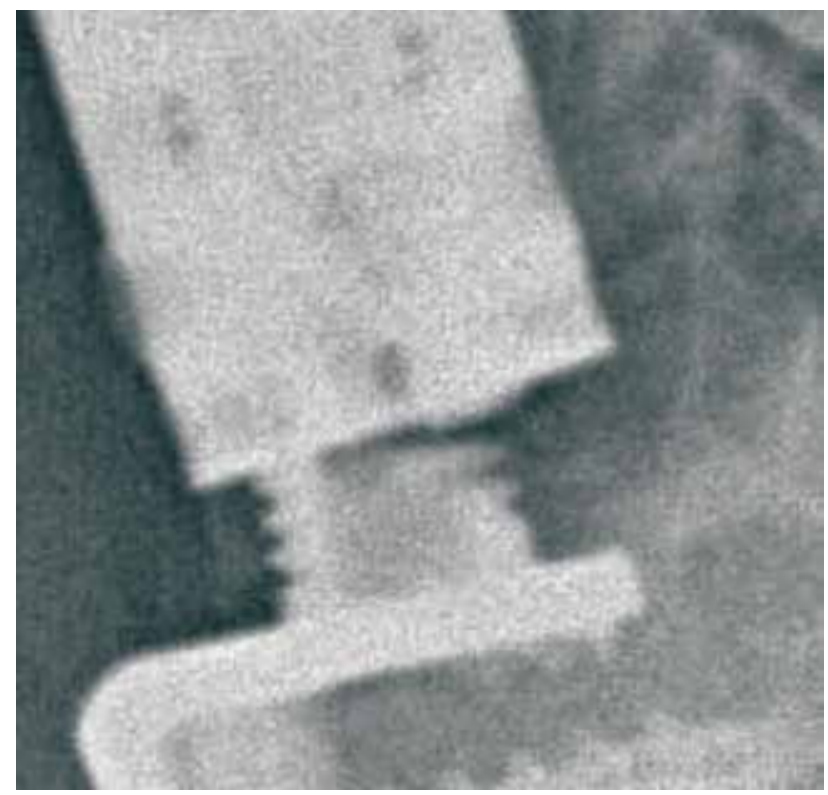

Figure 3. Lateral X-ray of cervical spine showing broken device.

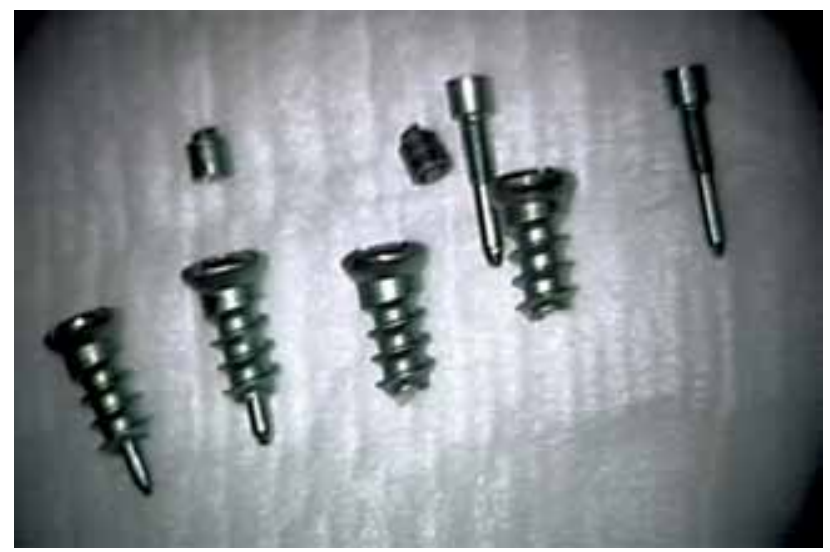

Figure 5. Broken osmium screws.

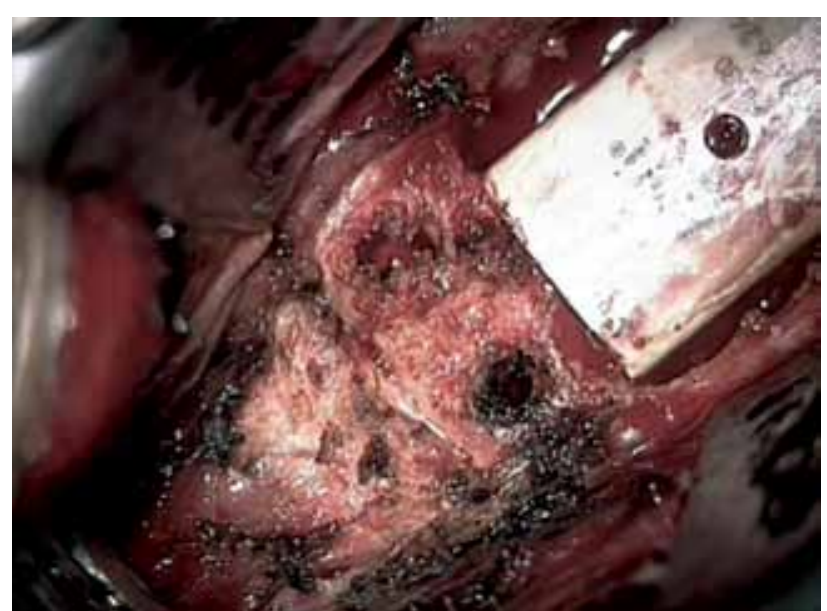

Figure 6. Intraoperative photo showing broken osmium screw holes.

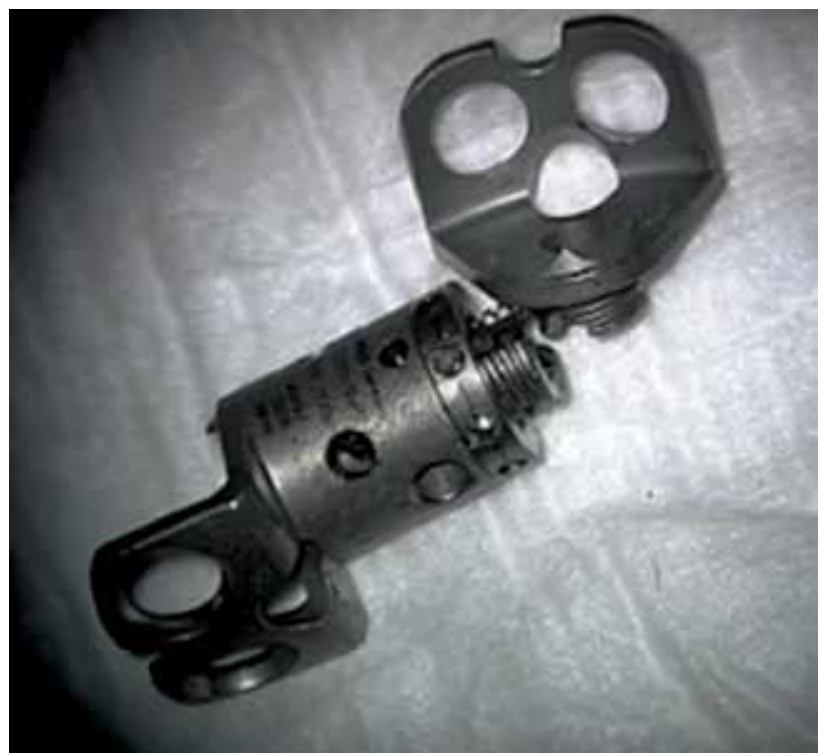

Figure 4. Lateral intraoperative X-ray of cervical spine showing broken osmium screws.
Figure 7. Intraoperative photo showing broken ADDplus device. 

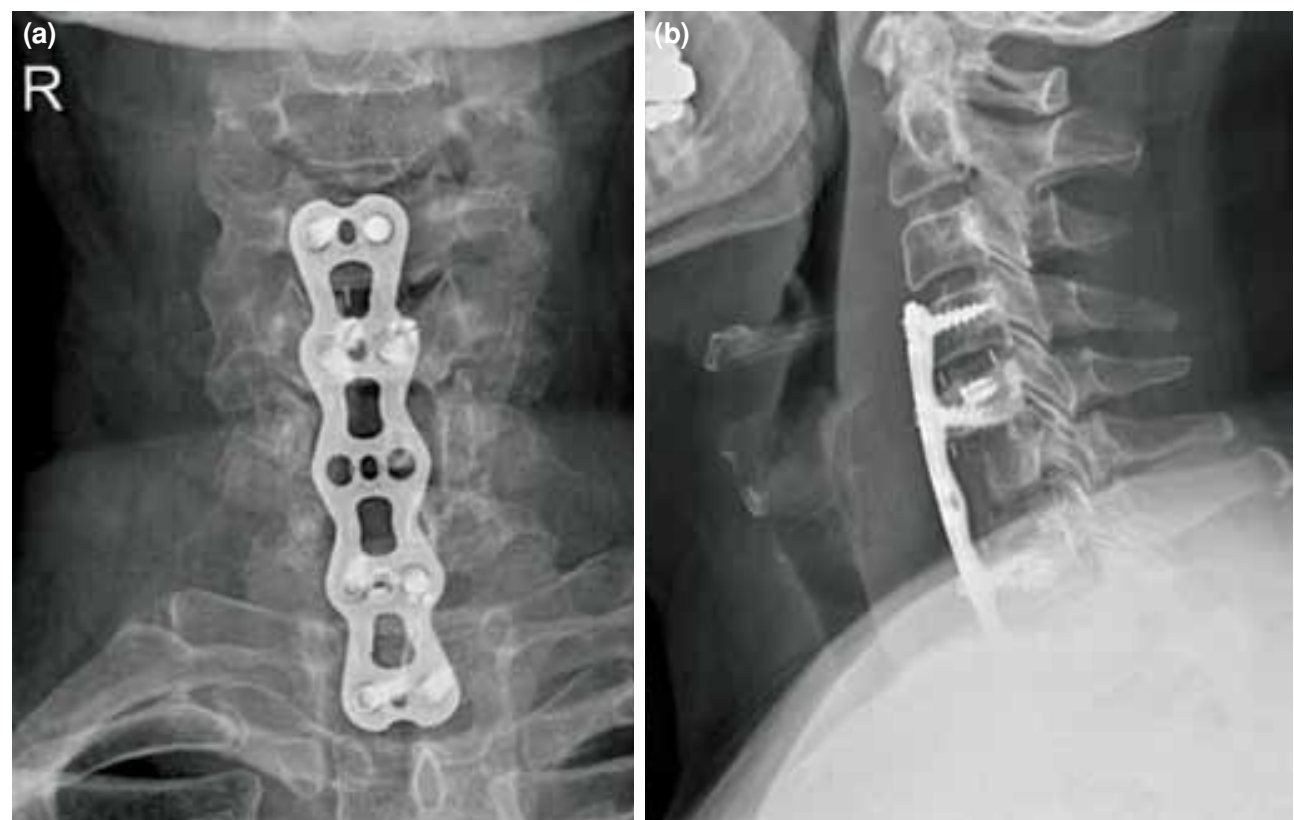

Figure 8. (a, b) Postoperative radiograph after definitive reoperation (a: anteroposterior view, b: lateral view).

and $\mathrm{C} 7 / \mathrm{Th} 1$ and a plate from $\mathrm{C} 4$ to Th1 with screw fixation in $\mathrm{C} 4 / 5 / \mathrm{Th} 1$. Postoperative course was complication free and the patient was without pain or neurological symptoms at follow-up after 12 months with all implants in radiologically regular position (Figures $8 \mathrm{a}$ and b). A written informed consent was obtained from the patient.

\section{DISCUSSION}

Treatment of cervical spondylotic myelopathy has developed via the anterior approach from single level discectomies to corpectomy with cage replacement. ${ }^{[1-5]}$ A new advanced method is use of expandable titanium cages which allow easy replacement with in situ expansion and reproduction of the sagittal profile. ${ }^{[9-13]}$ Stabilization can be achieved by additional anterior plating or posterior stabilization by a rod and screw system. Alternatively, a direct fixation of the cages with fixation wings is possible, a combination of two systems in one - cage and fixation system. . $^{[6,7]}$ Expandable cages are adjustable in height and can be inserted easier without the need to cut the edges, with fewer traumas to the endplates by in situ expansion. The kyphosis is progressively corrected with the expansion of the cage, while overdistraction must be avoided to preserve integrity of adjacent structures and prevent neurological complications. Treatment of cervical spondylotic myelopathy via anterior corpectomy results in postoperative neurological improvement and superior quality of life. Complications of the anterior approach are dysphagia, graft extrusions, and spinal fluid leaks. The incidence of dysphagia is different ranging from no high risk ${ }^{[12]}$ to one of 26 temporary $^{[1]}$ or $20 \%$ at six months, with an excellent fusion rate for single level corpectomy. ${ }^{[12,13]}$ Long segmental reconstruction for multilevel corpectomy is associated with a higher rate of failure between $9 \%$ and $67 \%$. A comparison of anterior distraction cages with plating $(n=16)$ or wing fixation $(n=28)$ revealed that the latter carries a higher risk of non-fusion and loss of lordotic correction and height at 12 months follow-up. ${ }^{[7]}$ Implantation is easier by direct attachment of fixation wings, but seems to have some additional risks. To our knowledge, this is the first report of breakage of the construct which needed the explanation of all parts. The removal of the osmium screws is not totally possible which comprises the following restabilization. The residual place for screws is reduced by big holes and residual screw residues. In our case, the indication for a longer stabilization was therefore somehow "lucky" because the plate could be fixed stable after inserting the monoblock PINA cage.

\section{Declaration of conflicting interests}

The authors declared no conflicts of interest with respect to the authorship and/or publication of this article.

\section{Funding}

The authors received no financial support for the research and/or authorship of this article. 


\section{REFERENCES}

1. Zaïri F, Aboukais R, Thines L, Allaoui M, Assaker R. Relevance of expandable titanium cage for the treatment of cervical spondylotic myelopathy. Eur Spine J 2012;21:1545-50.

2. Jandial R, Chen MY. Modified lateral extracavitary approach for vertebral column resection and expandable cage reconstruction of thoracic spinal metastases. Surg Neurol Int 2012;3:136.

3. Viswanathan A, Abd-El-Barr MM, Doppenberg E, Suki D, Gokaslan Z, Mendel E, et al. Initial experience with the use of an expandable titanium cage as a vertebral body replacement in patients with tumors of the spinal column: a report of 95 patients. Eur Spine J 2012;21:84-92.

4. Eleraky MA, Duong HT, Esp E, Kim KD. Expandable versus nonexpandable cages for thoracolumbar burst fracture. World Neurosurg 2011;75:149-54.

5. Robinson Y, Tschoeke SK, Kayser R, Boehm H, Heyde CE. Reconstruction of large defects in vertebral osteomyelitis with expandable titanium cages. Int Orthop 2009;33:745-9.

6. Ramírez JJ, Ramírez JJ Jr, Chiquete E, Gómez-Limón E. An expandable prosthesis with dual cage-and-plate function in a single device for vertebral body replacement: the clinical experience on 14 consecutive cases with vertebral tumors. J Neurosurg Sci 2011;55:189-95.
7. Cabraja M, Abbushi A, Kroppenstedt S, Woiciechowsky C. Cages with fixation wings versus cages plus plating for cervical reconstruction after corpectomy - is there any difference? Cent Eur Neurosurg 2010;71:59-63.

8. Atik OŞ. Are all case reports worth publishing? Eklem Hastalik Cerrahisi 2016;27:61.

9. Lau D, Song Y, Guan Z, La Marca F, Park P. Radiological outcomes of static vs expandable titanium cages after corpectomy: a retrospective cohort analysis of subsidence. Neurosurgery 2013;72:529-39.

10. Pekmezci M, Tang JA, Cheng L, Modak A, McClellan RT, Buckley JM, et al. Comparison of expandable and fixed interbody cages in a human cadaver corpectomy model, part I: endplate force characteristics. J Neurosurg Spine 2012;17:321-6.

11. Alfieri A, Gazzeri R, Neroni M, Fiore C, Galarza M, Esposito S. Anterior expandable cylindrical cage reconstruction after cervical spinal metastasis resection. Clin Neurol Neurosurg 2011;113:914-7.

12. Auguste KI, Chin C, Acosta FL, Ames CP. Expandable cylindrical cages in the cervical spine: a review of 22 cases. J Neurosurg Spine 2006;4:285-91.

13. Waschke A, Kaczor S, Walter J, Duenisch P, Kalff R, Ewald C. Expandable titanium cages for anterior column cervical reconstruction and their effect on sagittal profile: a review of 48 cases. Acta Neurochir (Wien) 2013;155:801-7. 